\title{
Implementation of the Holocaust: The Behavior of Nazi Officials
}

\author{
FRED E. KATZ
}

\section{The Johns Hopkins University}

Historical research has supplied extensive information about the stark facts of the Holocaust. It includes efforts both to document the full extent of the horror and to maintain a degree of objectivity and avoid undue sentimentality (Bauer 1978). The historical work includes, and goes beyond, chronicling the details of the murderous events. It points up unresolved-and possibly unresolvable-questions, such as the nature of the involvement and responsibility of European Christians. That issue involves, at one end, the accusation that Pope Pius XII was, at the very least, inactive in the face of a supreme moral challenge (Falconi 1970). At another end, it involves acknowledgement of extensive efforts by Christians to protect Jews, at considerable risk to themselves (Friedman 1980; Flender 1963).

Above all, the historical research illuminates not only the extreme brutality but the immense scope of the killings and the highly complex administrative processes that were needed in order to accomplish so vast an enterprise as the effort to exterminate millions of people (Hilberg 1967; Dawidowicz 1975; Shirer 1960). Vast material and human resources had to be harnessed. To a great extent the existing administrative structure of the German nation was utilized to accomplish the genocide. Utilized, too, were ideological antecedents to Nazism, such as the Urvolk theme, and a highly systematized indoctrination of the young (Koch 1975).

The administrative processes through which a nation enacts a program of genocide contain many sociological facets. Some of these are now beginning to be addressed. Horowitz $(1976,1980)$ has suggested that one needs to classify and analyze whole societies on the basis of whether they are acquiescent to genocidal practices- "whether and to what degree [a society] permits the official and arbitrary termination of lives of its citizenry" (1976:31).

Fein (1979) has examined how the different German-occupied countries 
responded to Nazi pressure to enact extermination policies against their Jewish populations. The countries varied greatly in the extent of their collaboration and in the resultant execution of the Nazi policies of extermination. Fein's theory is that this is due to the fact that the countries themselves differed in the following ways: (1) The degree of German control. Where there was lack of resistence to the Germans, where there was much cooperation with the Germans, victimization of Jews was extensive. (2) The degree of social solidarity in the country before the war. If, before the German invasion, there was strong solidarity, with Jews being included, there was little victimization of Jews after the German occupation. (3) The extent to which Jews had been included in a common "universe of obligations" before the war. Where such inclusion of Jews was the general rule, there was little victimization during the German occupation. Fein, like Horowitz, is emphasizing the bearing of a nation's social structure upon genocidal actions.

Wytwycky (1980) dwells on the fact that the Nazis conducted extensive extermination programs against a variety of peoples, not just against Jews. Gypsies, Poles, Belorussians, and Ukrainians suffered on the order of ten million killed through genocide, aside from those who died in military actions of the war. Wytwycky's work shows that the method of genocide-routine and efficient-was highly exportable. It was applied to different peoples, in different geographic regions. Sociologically, this fact demands that one seek explanations of genocide beyond that supplied by the unique circumstances of the Jews. Hence the present paper, although it concentrates on the genocidal persecution of Jews, attempts to raise sociological considerations that may be extended beyond the fate of the Jews.

There exists even today a relatively small body of sociological research on the Holocaust. Indeed, it has been said that "there is in essence no American sociological literature on the Holocaust"' (Dank 1979:129). The shortage may be due to the fact that when it comes to explaining extraordinary events social scientists operate under a severe handicap. As scientists we are inclined to look to the ordinary in order to explain the extraordinary. This means accepting the possibility that routine and mundane behavior can produce morally monstrous behavior, and that "extremist movements are not primarily the product of extremists" (Lipset and Raab 1978).

Looking to the ordinary to explain the extraordinary is inherent in the paradigms of the scientist. But these paradigms can become highly suspect, even repugnant, to the public when addressed to events seen as morally outrageous and uniquely abhorrent. For many who suffered in the Holocaust or whose kinsfolk were victims, the Holocaust is an evil that is utterly unique. For them, focus on the "ordinary" cannot do justice to the Holocaust. Insights of the routine, the mundane, cannot compare with insights of the poet, such as Nellie Sachs, or the novelist, such as Elie Wiesel, or the numerous 
autobiographical reports that dwell on the uniqueness, the incomparability of the Holocaust to any other event. ${ }^{1}$ There obviously is need for a reconciliation between two realms, that of the social scientist sifting the ordinary for clues to the extraordinary, and that of the morally outraged human being.

This essay tries to contribute to a reconciliation by a twofold approach. On the one hand, it attempts to develop scientific explanations; on the other, it attempts to link these explanations to the perceptions of laymen, where the monstrous nature of the Holocaust is only too real. Practically, this means taking "monster" perceptions seriously. Conceptually, it means trying to understand how exceptionally violent behavior can be practiced routinely and can, in fact, be incorporated into the day-to-day workings of a bureaucratic apparatus. Processes that produce this result-the routinization and bureaucratization of extremely violent behavior-are the focus of this study. Stated differently, we seek to discover what patterns of social structure and what patterns of personal immersion in a social situation serve to implement the program of an extremist movement.

Many analysts have recognized that bureaucracies have a potential for operating with moral blinders (Weber 1947, 1958; Merton 1968; Moore 1978; Kellman 1973; Silver and Geller 1978; Antonio 1979). The bureaucrat's focus on a particular task and particular work context can be accompanied by moral myopia. Considerations that go beyond the immediate task are apt to be ignored. Thus, in coping with problems of transporting Jews and Gypsies to extermination camps, or of the efficient use of wartime slave labor in munitions factories in the German Ruhr, the morality of killing people is obscured because it is beyond the particular bureaucrat's range of responsibility. In trying to comprehend this phenomenon, one needs to bear in mind that there was also a deliberate political campaign against the victims. They were portrayed as outcasts, as a species of lesser human, as vermin (Fein 1978). Doubtless this may have contributed to the bureaucrat's moral myopia as well as to the willingness to adopt extraordinarily cruel methods of killing. But one also needs to analyze the process of implementation, the process which carried out the political campaign, the process which acted upon the less-thanhuman presumption to annihilate people en masse.

Research on social movements and on routinization offers leads. It also offers indications of where the gaps in knowledge lie, and where further conceptualization is needed.

1 Sociologists (and historians) are also aware of the strong disagreement aroused by Hannah Arendt (1968, 1976). She pointed to the ordinariness, the "banality" of evil in the life of Eichmann. Part of the disagreement with her work arose because of her theme that the victims contributed heavily to their own demise. That theme is certainly questionable, given both the actual Jewish resistance that occurred (and not only in the Warsaw ghetto) and the overwhelming nature of the assault on the victims. 


\section{SOCIAL MOVEMENTS}

The literature on social movements, particularly that on extremist movements, has moved from focus on a specific mind-set and other personal characteristics of a movement's adherents to focus on conditions in the social structure that have generated social movements. The social structure can produce conditions of considerable strain, which is fertile ground for extremist movements. This can happen when social conditions produce dislocated and dispossessed individuals who then become candidates for recruitment into extremist movements (Kornhauser 1959). Or, there may be relatively specific strains that are endemic to existing social structures and which also nourish the development of extremist movements (Lipset and Raab 1978).

Both of these explanations are essentially "theories of mobilization" (Oberschall 1973; Tilly 1978; Zald 1979), that is, they elucidate how movements are generated and how they subsequently organize resources for achieving certain objectives. It has also been shown that existing conditions in the social structure influence the direction of social movements-whether, for example, such movements will be of the extreme right or extreme left-and the sorts of options that will be entertained within movements (Lipset and Raab 1978; Tilly 1964, 1978).

Operating in the tradition of Durkheim, the sociological scholarship has emphasized the importance of "social" factors. That is, much of what goes on in social movements is to be understood in terms of conditions outside of individual persons. There are social strains and dislocations, and social institutions can foster movements. These have input into the behavior of individuals who participate in social movements.

Nonetheless there is a crucial insight in that earlier perspective which focussed on the person, one that must not be ignored. It is that individual persons carry out the programs of social movements. This is the case even in mass societies, where it is easy to lose track of the contributions of individuals. It is also the case in authoritarian societies, where leaders have overwhelming power. There, too, individual persons implement the programs.

How, then, are individuals immersed in movements, especially in extremist movements that may demand violent behavior? How, in the course of mobilization, do individuals become linked to a movement? How do they participate after they are immersed in the movement? How do they manage to carry out violent programs, especially when these programs conflict with some aspects of their own upbringing? To these questions the present study addresses itself.

\section{ROUTINIZATION OF BEHAVIOR}

Max Weber's work on bureaucracy remains the central bench mark for any study of routinization. He emphasized routinization of behavior in the 
bureaucratic context. He pointed out bureaucratic conditions that are conducive to harnessing human resources. Bureaucracies coordinate the skills of diverse specialists and functionaries in the pursuit of goals that are subdivided into limited discrete tasks. Weber left a legacy of looking at such routinization both microscopically, within the confines of specific organizational settings, and macroscopically, as a part of the values and institutional order of a society. Both are clearly recognized by sociologists studying social organization and social psychologists studying sanctioned massacres and other organized violence (Parsons 1949; Williams 1970; Smelser 1963; Lipset 1963; Kellman 1973).

The miscroscopic legacy has led to the realization that individuals can be submerged in the context of organizations. The individual bureaucrat is apt to attach his morality to the discharge of assigned duties and not to the choice of ends (Milgram 1974). Means, rather than ends, dominate the bureaucrat's thinking and action (Merton 1968). An organization's objectives may be so fractionated into component parts that the end state is obscured, and that the question of performing good or evil deeds becomes irrelevant (Silver and Geller 1978). The individual working in a bureaucracy may simply not apply these kinds of judgments to his or her own activities. As Kellman (1973) noted, the capacity to be aware of evil in one's behavior is influenced by one's integration into a system of norms. And systems of norms are translated into concrete behavior arrangements-in one's work, in one's family, in one's community. In all of these one may, in Kellman's sense, become unaware of one's own evil behavior.

Etzioni developed an important modification of Weber's formulation in regard to routinization. He worked out a scheme for clarifying compliance in bureaucratic and other settings. This augments Weber's rather exclusive emphasis on control and authority, and concentrates on those who are subject to control, on followers rather than leaders, on middle and lower echelons rather than top echelons (Etzioni 1961). Etzioni postulates three different sorts of compliance patterns-alienative, calculative, and normative-that are found in different sorts of social settings. Katz has suggested that each form of compliance also includes a characteristic form of autonomy, or discretionary activity (Katz 1968, 1976). The uses of autonomy are crucial to the functioning and survival of any social organization. This perspective will be applied to the behavior of Nazi functionaries.

Blau (1955) demonstrated that routinization of bureaucratic activities does not preclude innovative activities. He showed that, on the contrary, bureaucratic functionaries (social workers, in this case) do innovate as a matter of course. The routine performance of their tasks includes, of necessity, a considerable amount of innovative activities. Yet these activities do not necessarily destroy the over-all orderly, bureaucratic setting in which they exist. Indeed, they can help sustain it. Routinization, one may conclude, includes not only 
definite controls, but definite sectors of autonomy. This theme is central to the following discussion.

Before turning to some characteristics of Nazism that seem to promote routinization of violent behavior it is necessary to insert a note about antiSemitism. The focus here on the bureaucratization of extremely violent behavior does not mean to imply that the middle-level bureaucrats, the subjects of this study, were not anti-Semitic and filled with hatred for Jews. It is plausible to assume that many were indeed deeply anti-Semitic. But the theme of this study is that one can account for a great deal of extremely violent anti-Semitic behavior without a basis in personal hatred for the Jews. It is assumed that a particular form of behavior, such as the killing of Jews, may derive from a wide range of motives, not necessarily those of hatred. This does not absolve Nazi officials from culpability for their deeds. And it does not accept the view that the individuals were merely following orders, that they had no choice but to execute orders that came from above. Instead, it is postulated that in their roles as bureaucrats these officials had a significant amount of autonomy. They exercised considerable discretion in the course of their murderous activities.

\section{SOME CHARACTERISTICS OF NAZISM：INCREMENTAL PROCESSES}

There is every indication that the Nazis had no clearly worked out plans for the extermination of the Jews before the party came to power in 1933 (Bauer 1978). The extermination evolved in a step-by-step incremental manner.

After the Nazi ascent in 1933, a progression of repressive laws against Jews was passed. These laws deprived Jews of an increasingly large number of rights, with each law more severe than its predecessor. Every new law was an increment in a cumulative process that culminated in Jews being deprived of virtually all rights of citizenship.

For example, on 23 July 1938, a decree was issued that ordered all Jews to apply for identification cards, to be carried at all times (Dawidowicz 1975). A law passed on 17 August 1938 ordered Jews to adopt, as of 1 January 1939, particular Hebrew-sounding names (Sarah for women, Abraham for men). Such steps would serve to identify Jews readily when it came time to round them up for transport to the death camps. But since the steps were taken legally, they could serve to coopt, in an incremental manner, the legal machinery of the state.

The gradual curtailment of rights eventually terminated virtually all Jewish rights of citizenship. This, in turn, was a crucial step toward the 1942 secret order directing the physical annihilation of all Jews in German-occupied territories (Schleunes 1970). The piecemeal nature of the legislative sequence deceived many, even many of the victims, into believing that the actual killing of Jews was unlikely to happen (Schleunes 1970). The series of ever more repressive laws generated a course of action so extreme that it might have 
proven unacceptable to the German people-and perhaps impossible to carry out-if it had been attempted in one single action, without the incremental build-up.

In a well-known series of experimental situations, Milgram (1974) showed that people who are asked to follow instructions tend to do so, even if the instructions are to hurt cruelly an innocent person. They do this although the behavior may conflict with their own broader values.

The participants in the Milgram experiments were asked to take part in a scientific experiment. It may be argued that their compliance with the instructions was a way of expressing their respect for a countervalue, namely the value of scientific research. But why accept this value when it is believed to hurt innocent people in this situation? Why could the value of scientific research here supercede humane values prohibiting the injury of innocent people? Presumably these participants would not deliberately hurt innocent people in other situations.

An explanation of the apparent paradox may be that people are able to separate behavior in a particular situation in which they may find themselves from behavior in other situations. It is a way of solving immediate problemsby accepting the regimen of the present situation-while giving little attention to broader issues (Silver and Geller 1978), or to long-term consequences. Here persons solve problems one at a time, dealing with what confronts them right now. Stated differently, immediate situations in which individuals find themselves can serve as catalysts for activating some values while deactivating others.

The restriction of behavioral focus to the immediate situation can have very unexpected consequences. The behavior can become the increments in a cumulative process that has truly monstrous properties. Documented life histories of a number of the Nazi SS officials demonstrate this. Hannah Arendt's study of Adolf Eichman (1976), the study of SS officers by the British psychiatrist Henry Dicks (1972), and the analysis of 581 biographies of early Nazis by Peter Merkl (1975), bear out the gradual nature of their becoming immersed in the Nazi programs. For example, the young Eichmann, following failures in education and work, was about to join an organization of youths dedicated to pranks and totally unpolitical recreational activities, when a friend asked him to join the Nazi party instead (Arendt 1976). Eichmann did join, but he evidently did so without commitment to, or even real knowledge of, the movement's ideology (Arendt 1976). He advanced in the movement in a step-by-step sequence while retaining reservations about the murder of Jews. He had some Jewish relatives. He claimed, perhaps with sincerity, to retain loyalty to these persons. He even proposed different solutions to the "Jewish question" -notably, that European Jews resettle in Madagascar.

But all this did not keep Eichmann from complete adherence to the Nazi program of destroying the Jews. That adherence meant his becoming a highly significant and even innovative functionary in the mass murders. Much of his 
activity was pursued with the view to furthering his personal career, rather than with an ideological commitment to hating Jews. His career was carried out in the context of the Nazi state machinery. To live effectively, for Eichmann, meant contributing to that machinery.

Incremental processes are very common. On the American national scene, for example, we find a great deal of ad hoc action in national policy making, in steering the economy, in carrying out reforms of welfare systems, in reorganizing bureaucratic procedures, in adapting to international pressures. Ad hoc activity means, in each case, that one adapts to pressures by trying to find immediate, stopgap answers. One makes specific and direct responses to immediate issues, rather than developing long-term plans and carrying these out systematically. (I am not saying that ad hoc action is instrinsically bad or good. Ad hoc action can scarcely be avoided in a nation based on pluralistic politics at home, where pressure groups are easily mobilized, and on complex international alliances abroad, where coexistence with some strange bedfellows is a necessity.)

It is not only the Eichmanns who develop their careers incrementally. In a study I did some years ago, it was evident that persons can enter into an occupational career by a series of localized, immediate decisions, and without any explicit commitment to that occupation at all (Katz and Martin 1962). For example, one may enter a nursing school because one's closest friend is attending that school, and for no other reason. One may continue in nursing school because it would be costly to drop out and start afresh in another occupation. One may then continue on and enter nursing as a profession. In this sequence there need be no special commitment to nursing. Yet a career in nursing is the result. And there is no evidence to suggest that such noncommitted nurses cannot carry out their profession fully, that they cannot be fullfledged, dedicated nurses.

Nurses are not unique in this respect. In every occupation there are likely to be persons who enter the profession by this same unplanned route. They incrementally carry out activities that lead to that particular occupation. They make decisions on an ad hoc basis, without ever having committed themselves to be in that occupation.

It is often assumed that a person who goes through lengthy occupational training is bound to pick up a commitment to that occupation during that course of training if a definite commitment to the occupation did not already exist beforehand. But this assumption should be regarded with skepticism. There are indications that persons can fully engage in an occupation without commitment to its core features. A particular teacher may not be committed to teaching, and yet be engaged in teaching. ${ }^{2}$ Or a particular physician may not

${ }^{2}$ Sylvia Ashton Warner, a greatly honored teacher, reports in her autobiography that she had not real commitment to teaching and that she did not enjoy teaching (1979). However, one illustrative example, such as this, tells us nothing about the prevalence of this circumstance. 
be committed to healing, and yet be engaged in healing. ${ }^{3}$ Each may have come to the occupation via an incremental process whereby the commitment to the core feature is minimal, at best. The real commitment may be, for instance, to careerism. And the career will, in turn, be embedded in a social context.

Eichmann and Heinrich Himmler, chief of the SS, represent extreme careerists. Both occasionally expressed misgivings about their murderous work. But this did not keep them from enthusiastically and inventively continuing in it. Himmler, while noting the horror involved in carrying out mass murders, proposed that SS members should not say, "What horrible things am I doing!" On the contrary, they should say, "What horrible things do I have to witness while carrying out my sacred duty!" (Dicks 1972; Crankshaw 1977). The emphasis is on the great contribution one is making to the sacred cause, to the immediate social context of which one is a part, especially by doing things that may be personally obnoxious.

Incremental processes lend themselves well to the practice of deception. They were so used by the Nazis at every step to obscure the direction toward mass murder (Dawidowicz 1975:202). Deception even occurred at the decisive conference on 20 January 1942, where the mass killing of Jews was specifically decided upon and the methods chosen for carrying this out (Hilberg 1967:102ff.). Deception also occurred in the transportation of Jews to the extermination camps. For example, the victims had to pay a fare for the train trip to their "relocation" (Hilberg 1967:114).

The individual increments-the acts of individuals inventing and executing ever more efficient forms of murder-are components of personal careers that are embedded in a social context. That context is, itself, a composite package that needs to be understood.

\section{SOME CHARACTERISTICS OF NAZISM: PACKAGED BEHAVIOR}

Nazism was a package, a composite of very diverse programs. ${ }^{4}$ This package included extreme anti-Semitism, strong nationalism (including the hope to

3 A study of surgeons reports that some surgeons have little commitment to surgery, but continue to perform it (P. Katz, n.d.).

4 The notion of a package, a composite of linked items that form one whole, bears similarity to Gestalt psychology. The Gestaltists, too, emphasized the "wholistic" unity of a setting, as against discrete and separate component parts of that setting. But the Gestaltists concentrated almost entirely on the psychology of perception, on how people perceive a situation. They did not dwell on the social organization of behavior that may accompany the Gestalt phenomena. In the present essay, by contrast, the social organization of behavior is the central concern.

The idea of a package is also similar to the anthropologist's conceptions of culture configurations and culture complexes. By these constructs anthropologists emphasize the diversity of items manifested within cultures. But the manner and degree of amalgamation of the diverse items within a culture configuration or complex are usually taken as given, not subjects to be empirically investigated and conceptualized in a theory. The present study, however, seeks to examine the manner in which the diverse parts are amalgamated and, at the same time, the manner in which those parts retain a degree of separateness. 
recapture all the land that Germany had had to give up as the result of World War I), ethnicism (including the romantic master race theme), and economic development (including new career possibilities for many who had suffered in the crash of the 1920s). All these components tended to be extensions of older, existing German values that were then being sanctified and reformulated. The ideology of German nationalism, for example, was built upon Herder's (1744-1803) concept of Volk. In its early versions, Volk referred to an organic, natural family, in contrast to the artificiality of the nation state (Koch 1975:5ff.). It was subsequently reinterpreted by the philosopher Fichte, to point to unique German individuality. Nazi ideologists gave it added meanings, particularly those of the romanticism and superiority of the German master race. These were used extensively in the indoctrination of children in the Hitler youth groups (Koch 1975).

Those persons who became leading figures among the Nazis were evidently attracted to different items in the Nazi package. It is likely that Julius Streicher, with his history of hatred for Jews, was heavily and primarily attracted by the movement's anti-Semitism (Crankshaw 1977). Eichmann was probably attracted by, and committed to, its bureaucratic career possibilities. Hermann Goering was apparently also attracted to its career possibilities, but on a higher level of seeking personal aggrandizement and power (Arendt 1968). All of them are likely to have seen at least one feature in the Nazi movement that offered links to something important in their own lives. Tilly (1964, 1978), Oberschall (1973), Zald and Ash (1966), and Zald (1979) have shown that social movements recruit not only drifters and the unattached; they also attract people with definite social interests and links, to which the movement caters.

Fanatical anti-Semitism was part of the Nazi package. It was linked to a number of existing and past components of German national life. Dawidowicz (1975:220) writes:

Layer upon layer of anti-Semitism of all kinds-Christian church teachings about Jesus, Volkist anti-Semitism, doctrines of racial superiority, economic theories about the role of Jews in capitalism and commerce, and a half century of political antiSemitism-were joined with the solder of German nationalism....

Doubtless many a person was attracted to Nazism because of its antiSemitism, although the proportion of Nazis that fall into this category is not known. In addition, it is very likely that Nazism converted many members to anti-Semitism after they joined the Nazi party. A third category consists of those who joined the Nazi party and actively participated in anti-Semitism but who nonetheless may not have had a personal commitment to anti-Semitism. Indeed, anti-Semitic actions could be carried out, with great zeal and persistence, by persons who may not have had a personal commitment to antiSemitism. Their commitment was to some other components of the Nazi package and to the acceptance of the total Nazi package. It is conceivable that 
deeds of noncommitted anti-Semites-those who were committed to, say, bureaucratic efficiency-may have been more pernicious than those of the committed anti-Semite.

For example, there is some indication that Eichmann had no pronounced hatred for Jews when he joined the Nazi party (Arendt 1976). Eichmann claimed that he was not anti-Semitic. Toward the end of his life he stated: "An anti-Semite I never was-no!" (Hilberg 1967:106). It is by no means certain that his claim, as he understood it, was false. If one believes Eichmann's denial of anti-Semitism, one is not thereby absolving him of responsibility for his behavior. This is discussed in the next section.

A belief that Eichmann's assertion may be true impels one to draw some powerful sociological conclusions about the nature of Nazism and, for that matter, about participation in other extremist movements. They include the possibility that people can be thoroughgoing participants in a program of action to which they do not wholly subscribe, and that people can be indifferent or opposed to some components of a movement's program, components in which they are actually engaged but for which their scruples are held in abeyance. Anyone who has served in an army knows that this is not a farfetched idea. Soldiers routinely disregard moral assessments of many aspects of their task of killing enemies. One should not be misled by the revulsion against killing that emerged among many soldiers in the Vietnam war. This was the exception rather than the rule. Usually military killings are carried out relatively unquestioningly. The soldier's moral commitment against killing ordinarily remains intact for nonmilitary contexts, that is, for the context of the civilian life package. While adhering to the total set of components of the package of military service, the soldier may retain scruples against killing, but they will be held in abeyance. In short, participation in killing does not necessarily mean a commitment to killing itself; people can be enthusiastic participants in programs to which they do not wholly subscribe.

The unquestioning participation in mass killing was particularly likely when the killing was routinized, as it was in the gas chamber operations. When the method of killing was not routinized, the participants were very likely to express revulsion. ${ }^{5}$ This took place when German soldiers, stationed behind the Russian front lines in 1941, were ordered to kill civilians and prisoners indiscriminately.

In the course of his career as an SS officer, Eichmann evidently did not have great personal commitment to every item of behavior in the SS package of behavior. And this was true for other SS officers (Dicks 1972). Eichmann expressed fairly explicit reservations for some items (Arendt 1976). But nevertheless he, and the other SS officers, carried them all out. He expressed

5 Here, and in a number of other parts of this essay, I am greatly indebted to an anonymous reviewer of the previous draft. 
unhappiness about the decision to annihilate the Jews, but he displayed the greatest zeal in its implementation. He was accepting the entire Nazi package of programs.

A variant of this pattern was exhibited by Rudolf Hoess, the commandant of Auschwitz, under whose command millions of Jews were murdered. In his diary, Hoess (1959) completely accepts the "need" to annihilate the Jews. He does so because he accepts the ideology that Jews were the ultimate enemies of Germany. Yet Hoess was able to maintain, to himself at least, that he did not hate Jews and that he was appalled by some of the cruelty exhibited by the guards under his command. In this situation, one component-namely, a particular ideology - so dominates that other components are largely ignored. Here, too, the entire package is accepted, even those components that are distasteful.

The acceptance of an entire package while having reservations about some of its components is a paradox. Yet it is a common enough paradox. In the daily execution of their occupations, individuals may be highly committed to some aspect of the work and not at all committed to other aspects. Nonetheless, they carry on with their jobs, including enactment of those aspects to which they are not committed. The individual's real commitment is very likely to be one or another item among the total number of items that constitute the occupation's total package of behavior. And yet the total package of behavior is being carried out.

Behavior packages can change. Individual items from one package can recombine with items from another package to form a new package. In a presently continuing study of social movements it is becoming evident that packages can indeed be changed (F. E. Katz, n.d.). Packages can be undone and the constituent behavior "repackaged." For example, in the 1930s followers of Father Charles E. Coughlin were involved in his package of populism and advocacy of fairly radical economic reforms, increasingly severe anti-Semitism, and political leaning toward the fascistic regimes of Hitler and Mussolini. But as the United States came to be drawn into ever firmer alliance with the enemies of Mussolini and Hitler, the Coughlin package became increasingly unacceptable to many of Coughlin's followers. That is, Coughlin's package contained one item-friendship toward Mussolini and Hitler - that came into ever sharper conflict with the official national policy of the United States. As war approached, a rival package emerged in full bloom. It was highlighted by loyalty to the country in time of emergency-as against supporting a potential enemy. The new package contained the components of military service, active economic and military help for America's European allies, considerable reorganization of the national economy, internment of persons of Japanese descent, and much more. This package was composed of some of the same items as Coughlin's package, such as nationalism, but they were assembled differently. That is, they were placed in conjunction with 
items which the Coughlin package did not include, and some Coughlin items were excluded altogether.

For many of Coughlin's followers, the new package, with its highlight of nationalism in a state of emergency, was one they could not resist, and they abandoned Coughlin. To be sure, Coughlin's own package also included a large amount of nationalism. But that nationalism was contained within a package very different from that encouraged by the federal government. Nationalism was being repackaged.

In a similar vein, some of the early appeal of Nazism was due to the fact that its program was a repackaged version of some existing themes of German national life, such as that of Volk, of German national exclusiveness. Highlevel army officers saw Nazism's fervent nationalism as something they could accept (Taylor 1953:59ff.). Nazism was not an utterly new series of programs. It did contain some new elements, but it was also a rearrangement of some existing ingredients of German culture, ingredients to which many were already committed. In short, individual items of culture may persist in the context of different packages. Similarly, too, when the Nazi youth movements were obviously winning a mass allegiance, some Catholic youth movements tried to repackage their own programs by including some of the Nazi items, such as paramilitary training and rifle practice.

\section{SOME CHARACTERISTICS OF NAZISM: AUTONOMY}

How much and what sort of autonomy did Nazi officials have? Were they merely following orders, as many claimed when they faced trial for murderous deeds?

Nazi officials were members of a state-organized bureaucracy. As bureaucrats, they were subject to administrative regulations and controls. During the trials of Nazi war criminals, accused officials frequently referred to these controls and to their own lack of discretionary power in carrying out orders.

The focus on bureaucratic control leaves a crucial component out of consideration. Bureaucrats do have considerable autonomy. Sociologists have shown that bureaucrats can carve out autonomy for themselves even when administrative rules seem to allow little leeway for it (Blau 1955). They have also shown that many forms of autonomy are built into the structure of bureaucratic organizations (Katz 1968, 1976). Such autonomy is part of the very fabric of bureaucracies. It is just as basic to the continuing operation of bureaucracies as are the controls.

When Nazi bureaucratic functionaries said they were merely following orders, they were hiding the fact that they had considerable amounts of autonomy. Their inventiveness in the course of their work, their flexibility when they wanted to be flexible, all demonstrated autonomy. To give an example: Eichmann displayed a great deal of ingenuity and adaptability in his work of devising ways of getting trainloads of victims to their final destinations. He 
was successful even during the latter part of the war when there was a severe strain on the German railroad system. At that point he made special trips to plead with this or that official who had insisted on using the trains to transport troops. His persistence even meant by-passing some of his own superiors. Indeed, at one point toward the end of the war, Himmler, who was Eichmann's over-all superior official as head of the SS, ordered Eichmann to stop the transportation of Jews to the death camps. (Himmler had not suddenly become a humanitarian. He was concerned about the advancing Allied armies discovering the Nazi atrocities. He was also under pressure to yield facilities, such as trains and manpower, to the German army in the last ditch effort to stop the Allied armies.) Eichmann, however, sabotaged this order and continued to transport the Jews (Arendt 1976). Here Eichmann was clearly demonstrating autonomy in accomplishing what he regarded as the mission entrusted to him in his position. He was also demonstrating that the bureaucratic system allowed for considerable flexibility for devising means of reaching objectives. It had enough built-in autonomy for the individual functionary to be inventive.

SS Major General Otto Ohlendorf similarly exhibited autonomy in implementing the mass murders (Crankshaw 1977). At the Nuremberg trials he admitted to killing over 90,000 men, women, and children on the Russian southern front. He prided himself, however, on the efficient and "humane", manner in which the killings under his command were carried out. He instigated methods whereby there was little delay once the victims knew what was in store for them. The killings were carried out with military precision and speed. Ohlendorf prided himself on thereby reducing mental strain, for both victims and executioners.

Eichmann exhibited autonomy in his bureaucratic zeal even after his capture by Israeli agents. Using a bureaucrat's style, he collaborated to a degree that astonished the agents. For example, after his capture in Argentina, his captors asked him to sign a document acknowledging his willingness to be brought to Israel for trial. He insisted on composing a document himself, in which he expressed the intentions of the Israeli captors in far more formidable bureaucratic language than his captors had done (Harel 1975).

Bureaucracies, Max Weber noted some sixty years ago, are effective instruments for getting complicated work done. They help coordinate the work of many different specialists. Priorities are arranged strictly so that objectives can be reached. Weber emphasized that bureaucracies were engines of social control, control geared to integrating and routinizing the work of many specialized functionaries. He was well aware that bureaucracies could be established for diverse purposes-for organizing military service, for organizing political administration of a region, for organizing a business concern. However, he probably did not imagine that his own country would establish a bureaucracy to routinize mass murder. He also did not imagine that the att- 
tonomy of bureaucratic functionaries could provide a crucial component for reaching murderous objectives.

In granting functionaries a measure of autonomy in the interpretation of rules, bureaucracies provide a mechanism for rationalizing horrendous deeds. ${ }^{6}$ When functionaries need acknowledge only adherence to rules, they can disregard their own independent contributions to murderous behavior. They can, then, concentrate on "technical" problems (Hilberg 1967:57-59), on the means rather than the end (Merton 1968). In recognizing the bureaucrat's autonomy, where he or she makes an independent contribution, one is clarifying where personal culpability exists.

When the Eichmanns invented ways of bringing victims to the death camps, they were operating within definite zones of autonomy. This autonomy was granted to them - and, to be sure, with ample encouragement to put it to useby the Nazi regime of which they were members. Within their zones of autonomy, Nazi officials enjoyed the exercise of much discretion. There they could, and did, innovate, elaborate, and amplify on the instructions they received. There, finally, lies their culpability.

In the folklore about bureaucracy, the individual bureaucrat is merely part of the machinery. He bears no responsibility for his actions. He merely follows rules. He does not make them. This is, of course, a very inadequate view of what actually goes on inside a bureaucracy. But it served as a shield behind which many a Nazi official tried to hide. And it may have served not only for public consumption, as the bureaucrat faced other people and tried to justify his activities. It may have been even more important as a framework for self-deception. To themselves, bureaucrats could justify deeds, no matter how novel or resourceful, on the basis that these acts were merely the result of following orders. Those above oneself bear the responsibility. The bureaucrat could therefore continue to hold a conception of self that was completely at variance with actual behavior within the bureaucracy. Thus, Eichmann could say, with apparent sincerity, that he was not anti-Semitic (Hilberg 1967:106).

During the Nuremberg trials, most of the Nazi officials, such as General Ohlendorf, exhibited an extreme version of the obedience-to-authority theme. They claimed that in carrying out the planning and execution of mass murders they were merely carrying out orders. Ohlendorf, for example, acknowledged during questioning by lawyers that he had had reservations about the morality of the killings. Why, then, did he carry them out? "Because to me it is inconceivable that a subordinate leader should not carry out orders given by the leaders of the state." When asked about questioning the legality of the orders, "Ohlendorf replied, perplexed: 'I do not understand the question; since the order was issued by the superior authorities, the question of legality

6 I am indebted to Carl Sheingold for this insight. 
could not arise in the mind of [us] for [we] had sworn obedience to the people who issued the orders'" (Crankshaw 1977:141).

The interpretation of the court, and of many social analysts, was that such statements were a denial of personal responsibility for actions that (a) demand much personal initiative and (b) were so extreme that the orders, even if legally promulgated and delivered, should have been disobeyed. But this point of view does not adequately capture the sense in which Ohlendorf's autonomy was important to himself. The general's statement demonstrates that by obeying orders, even difficult orders, the officer is making a contribution to his status' honor, to use Max Weber's term. After all, has he not sworn to carry out orders? When would he be making the greatest independentautonomous - contribution to the honor of his status, when carrying out orders that are easy or when carrying out orders that are difficult, even repugnant? ${ }^{7}$

The same theme was noted by Himmler. In the speech to SS leaders cited earlier, he recognized the moral and emotional difficulties involved in participating in mass killings. He emphasized that by participating in such abhorrent activities, they were actually contributing to a "grand historic mission." Instead of dwelling on the horrible things "I am doing," they should dwell on the horrible things "I have to witness while carrying out my sacred duty." They should regard themselves as killers making a contribution to their honor, and should take pride in that contribution (Crankshaw 1977).

The bureaucrat who says he was merely following orders ignores his own originality in the course of his contribution. We have seen that the Nazi functionaries had considerable autonomy. The people at the top of bureaucracies have autonomy to make the big decisions. They formulate policies. But their underlings also have considerable autonomy, even when they claim that they do not. This is only too well known to anyone who has to deal with a bureaucrat. It is true that bureaucrats base their work on law, on existing rules, and on orders received from persons above them in the hierarchy. But

\footnotetext{
${ }^{7}$ Kingsley Davis (1949:93-94) set the stage for this insight by distinguishing between prestige, the rank accorded a social position, and esteem, the evaluation of a particular individual's performance of the responsibilities in that position. However, Davis and a subsequent generation of scholars have emphasized assessments of a position and of an individual made by other persons, not by the individual who occupies the position. What is thereby omitted is that the position's occupant can personally have a sense of contributing to the position's honor. This can happen (a) whether or not the position is itself ranked highly in relation to other positions and (b) whether or not the occupant is rewarded by esteem from others.

Even a person holding a low-ranked position may have a sense of status enhancement, of contributing to the honor of the position occupied and, thereby, derive a sense of dignity. (The traditional English butler, proud and urbane, is an example.) What is crucial is that the individual derives satisfaction not only from the relation of his position to other positions and not only from the esteem of others. The individual can also derive satisfaction from believing that he is making a contribution to the honor of his position. In making such a contribution the individual may exercise considerable autonomy.
} 
they can carry out orders with zeal or, figuratively, they can drag their feet. They can destroy the spirit of the law by insisting on the letter of the law. Or they can bend the letter of the law to achieve the spirit of the law. They can interpret orders in many ways. This behavior is common and "normal" in any bureaucracy. It involves using the bureaucrat's existing autonomy, the sort of autonomy that Nazi functionaires had in ample supply.

When bureaucrats deny their own contributions they are practicing selfdeception. One need not be a monster to engage in such self-deception. Indeed, it is possible that many a bureaucrat indulges in it to some extent as part of the "ordinary" day-to-day activity. Yet ordinary bureaucratic behavior, like ordinary incremental behavior and ordinary packaging of behavior, can become an ingredient contributing to monstrous deeds.

CONCLUSION

Sociologically the Holocaust is one instance of a genre of social behavior. Massive social violence is not unique. The Holocaust is unique only in its extreme amount of concerted violence. Implementation of the Holocaust depended to a considerable extent on behavior that is ordinary and mundane. As sociologists we begin by dwelling on the ordinary. Therefrom we may eventually extract and contribute knowledge that can curb transformation of the ordinary into the monstrous and the malignant.

Some of the "ordinary" behavior that existed in the Holocaust phenomenon can be conceptualized as follows:

(1) Clarification of where autonomy lies also clarifies where inventiveness, for good or ill, can be practiced.

Knowing where an individual's autonomy lies clarifies where his personal culpability lies.

The Nazi programs gave Nazi functionaries considerable autonomy. They used it to tailor bureaucratic techniques to a task, the attempt to annihilate a particular population, the scale of which had not been attempted before.

Autonomy often goes unrecognized, even one's own. This can serve as a mechanism for rationalizing horrendous deeds.

(2) A person's involvement in a social movement or in a personal career may result from a series of incremental decisions. These can focus on solving immediate problems, one at a time, without regard for wider concerns. This limited outlook can result in a lack of response to the moral issues involved in the total course of action by the persons who are, in fact, carrying out that course of action.

It is not known how many Nazi officials acted in such incremental fashion. Nor, for that matter, is it known how common incremental decision making is generally or how culture specific it is. But it is clear that Eichmann was not alone among Nazi officials in the incremental way in which he became immersed in executing Nazi policies (Schleunes 1970). 
(3) Nazism included a variety of political, economic, and racial programs which were amalgamated to form a cohesive package. Because of this amalgamation, adherents to one of the component programs were likely to implement the entire package of programs, even those programs to which they had no strong personal commitment. This behavior dovetails with the incremental decision process - in both it is a question of evaluating only some components of a larger entity in which one is, in fact, participating.

The Nazi package of programs contained some new items. But since it was also a repackaged version of some previously existing themes of German national life, it could appeal to people by relying on previous affiliations and commitments. (Oberschall 1973; Tilly 1978; Zald and Ash 1966; Zald 1979) It was a matter of repackaging existing allegiances rather than depending on entirely new ones. In this process some new ingredients were added, notably extremes of anti-Semitism. The new items became acceptable because they were part of a larger package, a package that promised revitalization of the national honor and the economy. The extreme anti-Semitism of Nazism was, at the same time, an incremental increase of the longstanding Western antiSemitism (Dawidowicz 1975); it was a repackaged form of earlier antiSemitism.

The combination of behavioral autonomy, incremental decision making, and packaging of behavior helps to explain how some of the officials were able to participate in an extremist movement. They help explain, also, how these officials could engage in routinized mass murder.

In future work, the great variation in the degree to which the different German-occupied countries cooperated in the genocidal process can be examined in the light of the concepts of incrementalism, packaging, and autonomy. Provisionally, and building upon Fein's work (1979), one can say: (1) In countries where Jews were previously defined as being outside a "universe of obligations," the ideology underlying Jewish genocide was but an incremental addition to an already existing orientation. It was not drastically new. The new ideology and its application in practice were therefore readily acceptable. (2) Where German control over the occupied country was strong, the German government was in a position to repackage the country's social structure, incorporating much Nazi policy in doing so. (3) Those leaders in occupied countries who favored the Nazi programs were given considerable autonomy to enact Nazi policies. Leaders who opposed those programs were severely restricted in the capacity to act if, indeed, they were allowed even to live.

\section{REFERENCES}

Antonio, R. J. 1979. "Domination and Production in Bureaucracy.' American Sociological Review, 94:6, 895-912.

Arendt, H. 1968. The Origins of Totalitarianism. New York: Harcourt, Brace and World. 
1976. Eichmann in Jerusalem: A Report on the Banality of Evil. New York: Penguin Books.

Bauer, Y. 1978. The Holocaust in Historical Perspective. Seattle: University of Washington Press.

Blau, P. M. 1955. The Dynamics of Bureaucracy. Chicago: University of Chicago Press.

Crankshaw, E. 1977. Gestapo. Moonachie, N.J.: Pyramid Publications.

Dank, B. M. 1979. Review of "On the Edge of Destruction," by Celia S. Heller, Contemporary Sociology, 8:1, 129-30.

Davis, K. 1949. Human Society. New York: Macmillan.

Dawidowicz, L. 1975. The War Against the Jews, 1939-1945. New York: Holt, Rinehart and Winston.

Dicks, H. 1972. Licensed Murder: A Socio-Psychological Study of Some S.S. Killers. New York: Basic Books.

Etzioni, A. 1961. A Comparative Analysis of Complex Organizations. New York: Free Press.

Falconi, C. 1970. The Silence of Pius XII, B. Wall, trans. Boston: Little, Brown.

Fein, H. 1978. "A Formula for Genocide: A Comparison of the Turkish Genocide (1915) and the German Holocaust (1939-1945), " in Studies in Sociology, I, in R. Tomasson, ed. Greenwich, Conn.: JAI Press. 1979. Accounting for Genocide: National Responses and Jewish Victimization during the Holocaust. New York: Free Press.

Flender, H. 1963. Rescue in Denmark. New York: Simon and Schuster.

Friedman, P. 1980. Roads to Extinction: Essays on the Holocaust. New York: Jewish Publication Society of America.

Harel, I. 1975. The House on Garibaldi Street. New York: Viking Press.

Hilberg, R. 1967. The Destruction of European Jews. Chicago: Quadrangle Books.

Hoess, R. 1959. Commandant of Auschwitz, C. Fitzgibbon, trans. Cleveland: World Publishing Company.

Horowitz, I. L. 1976. Genocide: State Power and Mass Murder. New Brunswick, N.J.: Transaction Books.

1980. Taking Lives: Genocide and State Power. New Brunswick, N.J.: Transaction Books.

Katz, F. E. 1968. Autonomy and Organization: The Limits of Social Control. New York: Random House.

1976. Structuralism in Sociology: An Approach to Knowledge. Albany: State University of New York Press. n.d. "Social Movements." Unpublished study.

Katz, F. E., and Martin, H. W. 1962. "Career Choice Processes." Social Forces, $41: 2,149-53$.

Katz, P. n.d. "Surgeons." Unpublished study.

Kellman, H. C. 1973. "Violence without Moral Restraint.' Journal of Social Issues, 29:4, 25-61.

Koch, H. W. 1975. The Hitler Youth: Origins and Development, 1922-1945. New York: Stein and Day.

Kornhauser, W. 1959. The Politics of Mass Society. Glencoe, Ill.: Free Press.

Lipset, S. M. 1963. Political Man. New York: Doubleday Anchor.

Lipset, S. M., and Raab, E. 1978. The Politics of Unreason, 2d ed. Chicago: University of Chicago Press.

Merkl, P. H. 1975. Political Violence under the Swastika: 581 Early Nazis. Princeton: Princeton University Press. 
Merton, R. K. 1968. Social Theory and Social Structure. New York: Free Press. Milgram, S. 1974. Obedience to Authority. New York: Harper and Row.

Moore, B., Jr. 1978. Injustice: The Social Bases of Obedience and Revolt. White Plains, N.Y.: Sharpe.

Oberschall, A. 1973. Social Conflict and Social Movements. Englewood, N.J.: Prentice-Hall.

Parsons, T. 1949. The Structure of Social Action. Glencoe, Ill.: Free Press.

Schleunes, K. A. 1970. The Twisted Road to Auschwitz: Nazi Policy toward German Jews, 1933-1939. Urbana: University of Illinois Press.

Shirer, W. L. 1960. The Rise and Fall of the Third Reich. New York: Simon and Schuster.

Silver, M., and Geller, D. 1978. "On the Irrelevance of Evil: The Organization and Individual Action." Journal of Social Issues, 34:4, 125-36.

Smelser, N. 1963. Theory of Collective Behavior. New York: Free Press.

Taylor, T. 1953. Sword and Swastika. London: V. Gollancz.

Tilly, C. 1964. The Vendee. Cambridge: Harvard University Press. 1978. From Mobilization to Revolution. Reading, Mass.: Addison-Wesley.

Warner, S. 1979. I Passed this Way. New York: Knopf.

Weber, M. 1947. The Theory of Social and Economic Organization, T. Parsons, trans. Glencoe, Ill.: Free Press.

1958. From Max Weber: Essays in Sociology, H. Gerth and C. W. Mills, trans. New York: Oxford University Press.

Williams, R., Jr. 1970, American Society. New York: Knopf.

Wytwycky, B. 1980. The Other Holocaust: Many Circles of Hell. Washington, D.C.: The Novack Report.

Zald, M. 1979. "Macro Issues in the Theory of Social Movements.' Paper presented at American Sociological Association Meetings, August 1979, at Boston, Mass.

Zald, M. and Ash, R. 1966. "Social Movement Organization: Growth, Decline and Change." Social Forces, 44:3, 327-41. 